\title{
COVID SOCIALISATION, STIGMA AND DEHUMANISATION IN INDIA: A NEED FOR NEW EDUCATION
}

\author{
Dr. Mohan Singh
}

\section{Abstract:}

The socialisation since childhood, constructs our consciousness about the world which decides our behaviour in the world through differences :superior/inferior, we/they etc. Same way, the socialisation during corona pandemic called, covid socialisation also creates 'we' and 'they' among the people by stigmatising few as 'they' who are infected by the virus or suspected carriers of virus. And 'we' who are feared of being infected by covid-19 discriminate and dehumanise 'they' people with insensitivity. To remove this stigma, a new education is required which make people sensitive to all without any differences.

Key words: 1. Social stigma 2. Covid Socialisation. 3. Dehumanisation 4. Discrimination

\section{Introduction}

The arrival of Corona pandemic, because of covid-19 virus, has killed thousands of people across the world. In India also, many people are infected and killed by the virus. Because of this, there is fear psychosis all around: fear of being infected by the virus. In such a pandemic situation, the victim and vulnerable people especially, young and very old people need care, sensitivity and empathy from society and governments. The social institutions as family, religion, media and education are expected to play a positive role in such a sensitive time.

But the reality on the ground shows a different story: The people who are infected by corona virus, instead of getting sensitivity and empathy, are being stigmatised and facing discrimination and violence in the society. The health care institutions across the world becoming unable to ensure the democratic rights of the infected people. Labourers are migrating from cities to their villages out of the fear of being infected by virus and loss of job. Even the united states, having modern science and technology could not assure democratic rights to its people. Because thousands of people have died by covid-19, also became jobless because of corona pandemic. In such a situation, all claims of modernity appears childish because affected people are feeling helplessness, and government also is unable to help because of limitations. In this pandemic situation, people infected by covid-19 deserve sensitivity and empathy from the society. But, instead, they are facing selfish and insensitive treatment in the form of hate, discrimination and brutality because of covid socialisation through the institutions of society in the name of health care and information. 
Towards Excellence: An Indexed, Refereed \& Peer Reviewed Journal of Higher Education / Dr. Mohan Singh/ Page 18-25

The helplessness of people in this pandemic exposes the hypocrisy of modernity which claim of equality, dignity and respect for the individuality to people. As thousands of people are walking hundreds of kilometres to their home town, hungry, without transport and medical facility. Health institutions have become failed across the world. As more than a million people have died in US, because of Corona virus, which has modern health infrastructure for its citizens.

Even the dignified death is not given to the corona victim. As many dead bodies were seen unattended for many days. Even, there is a shortage of place to cremate people.The corona pandemic also have exposed the fake love or emotion of the family for its members. Because the dead body of the victim were not being accepted by their family members in few cases.

Objective :It is to understand, how, covid socialisation, in the name of information about health security and information create stigma resulting to discrimination and violence against people who are infected or suspected to be infected by covid-19 virus. Hence, visualise about a new education which connect people and make them sensitive and humane to all people irrespective of differences.

Stigma and Dehumanisation: a conceptual Understanding.

In common sensical language stigma is something which makes people to segregate, differentiate or reject the 'other'. And this stigma can be for cultural, behavioural or physical characteristics. According to Goffman(1963), social stigma is an attribute, behaviour or reputation which is socially discrediting or reputation which is discrediting in a particular way: it causes an individual to be mentally classified by others in an undesirable, rejected stereotype rather than in an accepted, normal one. And this stigma consciousness divides society into 'we' and 'they'. Let us understand, how do we become aware of this 'we' and 'they' in the society. We become aware or conscious about the objective world through the socialisation process, which we experience in our daily experiences of the senses. And these experiences condition us by making our memories.

These experiences of socialisation construct our memories about the world. And on the basis of memories of past, we make judgement about the world and miss the life in presence. Because, we do not accept life as it comes, rather make judgement on the present from the past experience by judging world 'good' or 'bad' which divides society into 'we' and 'they'.

In simple words, we wants the things of our life to happen as per our choices which are created by the socialisation. And those things which do not go as per our choices are disliked by us. And disliked or discriminated one is stigmatised. And that is how 'we' people perceive 'they' as problem. That is why, because of our socialisation, we perceive life as problem. And to solve the problem, we try to connect our problem to a cause.

But our causality also is habitual process of mind. According to David Hume( 1739-40), our faith in Induction and causation is the result of mental habit. For him, one event following the other do not become the cause of other. As dropping the rubber ball on ground do not become the cause of its bouncing. These are the selective experiences given by 
Towards Excellence: An Indexed, Refereed \& Peer Reviewed Journal of Higher Education / Dr. Mohan Singh/ Page 18-25

socialisation which become fixed in our mind. Such experiences when become memories makes our identities. In simple words, causal connections are the habits of mind created by the sensual experiences of socialisation.

Extending the Hume's argument, that we cannot know the world beyond the experience, Kant (1771) in his 'critique of pure reason' says, our limit of knowing, or limit of reason is decided by the existing impressions or categories created in the mind by the sensual experiences. And possibility of knowledge about the world do not go beyond these impressions of mind given by sensual experiences. That is how, he synthesised empiricism and rationalism.

In simple words, according to Kant, our knowledge of the external world do go beyond the existing concepts of the socialised mind. He critiqued Descartes and Newton, who celebrated 'reason', saying: ' we can know the world through rationales of mathematics, hence we can know the God', they said.Edmund Husserl(1963) also builds up in the same line in his 'phenomenology' and questions the objectivity of science saying: man knows the objective world through his subjectivity: an appearance of reality is a reflection of subjectivity. The point to understand is: It is the socialisation which creates a differentiated perception about the people in the objective world, i.e. stigma, stereotype about the people. Hence, we cannot think beyond the mind created by socialisation. That is why, Levi Strauss(1962) says, savage and modern mind are similar and argues in his 'savage Mind' about the similarity in structures between savage and civilised minds which according to him exists in the structure of nervous system: between mind and experience. He further says, human mind is full of binary oppositions through which it makes meaning about the world.

Our very perception about the world do not go beyond the differences constructed by the socialisation: it creates a categories of class, caste, gender, religion, language and race in the name of peace, truth, democracy etc.These Categories are constructed in which one category is constructed as inferior and hated by the 'other'. In the case of 'gender': one gender is constructed as inferior against the 'other'. In the case of class: Hate is constructed between rich and poor in the name of equality by theory of Karl Marx. In the case of race, black is created as inferior and 'hated' by the white and vice versa. That is how, our minds are constructed through the memories about the people in the objective world which are perceived as threat to our identity. And 'we' resort to violence out of phobia with 'they' category of people. Because, we are socialised to experience the world in a fixed manner :Accept some and reject some by differentiating on the basis of their shape, dress, food, gender, class, behaviour etc. That is how the identities of class, gender, caste, language and colour are constructed.

In other words, our socialisation process is nothing but creation of minds through should and should nots, which makes norms for the people. Those who follow the norms are called normal or 'good' and others are marked as 'abnormal' or 'bad' people. And these 'abnormal' people are marked, identified or stigmatised, leading to hate, discrimination and violence. Because, they are the reason of phobia for the 'good' people or 'normal' people. And those 'bad' people are disliked or discriminated through stigma or stereotypes and become victim of hate or phobia from the 'good' people. 
Hence, there is a constant fight between 'good' and 'bad' people who cannot co-exist together. Because the socialisation through ideology has constructed our worldview of 'we' and 'they'. That is why, Jacques Derrida, talks about deconstruction of the logocentrism. For him, logic of the language makes meaning only in binaries: man/woman, Jew/Christian, black/white, reason/madness etc. And these binaries privilege one over the other, resulting to repression of the 'other', both can not live in coexistence.

Not only religion and science, mythology also constructs our consciousness about the world which was thought, before the arrival of science, as something superstitious or the product of primitive mind. Myth may not be historical fact but it construct a worldview responsible for history. Look, how Alexander was impressed by the Homer's lliad and wanted to become like Achilles a character in it. He killed millions of innocent people and becomes 'great'. That is how, human beings are conditioned by the socialisation. The socialisation through tradition and modernity( includes mythology, religion, education science and technology) creates our minds full of hate, dislike or fear because of which we discriminate or resort to violence with the stigmatised people.

Socialisation during pandemic:

The socialisation of people during the corona pandemic, called covid socialisation, created fear in the mind of people: fear of being infected by the corona virus. Because of the fear consciousness, people differentiate from those who are affected by virus or are possible carriers of covid-19 virus. Such people are: 1)those people affected by covid-19 virus. 2) Health personnel who are engaged in the care of infected people. And these people are being stigmatised resulting to discrimination and violence against them because of covid socialisation from different means in the name of prevention and cure from covid-19 virus.

Media: The media and social media through its information about prevention and treatment news and daily update of death tolls by corona virus create fear in the mind of people because of which a consciousness of discrimination is created in the mind of people.

Mobile phone: Before talking to the other, precautions are told which load us with dangers of corona: It is about making physical distance and use of sanitisers etc.

Songs on Corona: Creativity of artists, singers etc aggravated the fear of corona in the minds of people, as a song in Kannada, informing people not to eat outside, not to call people home and not to travel outside at all: "Kak carona----"

Expert opinion: 'Health expert' across the world predicting death toll in millions in India also create a fear psychosis in the minds of people.

Too many webinars: Webinars on covid 19 during the Lock downCreated a fear consciousness in the name of awareness about covid-19.So,an environment is created as if there is nothing other than corona virus in life.

Use of Mask and sanitisers: It creates too much fear in the mind of people, without mask and sanitisers people feel vulnerable. When people go to market, and see all are wearing 
Towards Excellence: An Indexed, Refereed \& Peer Reviewed Journal of Higher Education / Dr. Mohan Singh/ Page 18-25

mask, as if something terrible is happening, and people are making differences. This created a consciousness of fear in the mind of people.

Physical Distancing in public life: People in public and private sphere speaking at a distance creates a consciousness as if something is going wrong in the society: it creates a fear or suspicion in the mind of people suspecting everyone as possible carrier of virus.

Refusal to accept of dead body by family: There were news in the media about refusal to accept even the dead body of corona affected patient by the concerned family itself.

Funeral disciplines: Even death is not allowed to happen by law as it used to happen before. So the fear of virus goes to the extent that it gives a sense of insecurity of not being looked after by the near and dear ones with respect even after death. This gives an emotional insecurity to the people, which creates more fear in the mind of people.

Police mike in the town: Police informing people in the town by loudspeakers not to come out of house. It creates a curfew like situation because police generally informs through mike in public when there is some problem. It creates a sense of insecurity in the minds of people.

Refusal to burry or cremate the dead body by locals: The dead bodies of people because of corona virus infection were not allowed to be buried or cremated by some people in their locality because of the fear of being infected.

Ambulance carrying Corona patient with hooter on: The ambulance carrying dead body of Corona infected patients through the town by making noise become matter of discussion in onlookers who discuss the same thing in their homes. So, the talks in the private and public spaces becomes an issue making a fearful climate in the society.

Death toll in US: The death toll in US becomes a big concern. Thinking: in-spite of their health standard higher then India their toll has crossed more than one hundred thousand. That makes people more fearful.

Dehumanisation:

Life is all about sensitivity and empathy. But socialisation makes us insensitive to the life. The socialisation of people during the Covid-19 pandemic created a consciousness of fear in the minds of people, because of which people started discriminating the infected people who are carrier or possible carriers of covid-19. The discrimination resulted to dislike or hate for the infected people, also violence against them. This dehumanisation can be seen in the following forms.

Insensitivity: Life is full of sensitivity and empathy for all. But the socialisation construct insensitivity in the name of health or security. The covid socialisation makes people insensitive towards infected people, who deserve sensitivity, especially at this pandemic time.But, instead of sensitivity, today, man is reduced to a virus: he is known through the virus. We do not see human being but see only virus first. This is dehumanisation of human being: not giving a dignity to the human being as claimed by tradition and modernity. 
Self -suppression: The stigma created by socialisation not only leads to insensitivity for the others who are infected by virus, but also for the self. Because of the fear of being stigmatised, people do not disclose their disease and suppress it. These stigmas are dehumanizing because they are against the freedom and individuality of human being. Interesting thing is: the stigmas are created by the very society which claims to have the values of peace, harmony and democracy.

Discrimination:

Stigmatised people experience discrimination in public and private spheres in following ways:

1.The stigmatised people are being discriminated economically as some people are not purchasing vegetables from the thelas of those who are stigmatised.

2- Discrimination in the provisional stores because stigmatised people face stereotypes by discrimination.

3-Discrimination in public park as stigmatised people are not allowed to walk.

4-Discrimination while social mingling.

5- Discrimination even by family members for refusing to accept the dead body of the of the covid-19 infected person.

6.discrimination in renting house with the infected person.

Violence: The stigma resulted to the violence which is known to the people through media. Following are few examples.

1.violence on health staff

2. violence on police

3. violence with a stranger.

4.Violence on particular category of people.

Need of new education:

The socialisation process disconnect us from the life. Because it creates a conscience of hate and fear by constructing 'we' and 'they' in the society. Hence we need to connect people with life which is only possible by a new kind of education based on facilitation, not by imposition. The new education would be: allowing people to know their nature. This is possible through mind watching, music, dance, laughing and sports with awareness. This would connect people with life and make sensitive and inclusive to all human beings.

Conclusion:

The socialisation construct our minds against life. Because it constructs hate and fear for the other human being in the name of truth, peace, democracy etc. But life is full of sensitivity and empathy for all. In the case of Covid-19 also, the socialisation creates fear and hate for 
Towards Excellence: An Indexed, Refereed \& Peer Reviewed Journal of Higher Education / Dr. Mohan Singh/ Page 18-25

the infected person. Hence, we need a new education which would connect us with life and would make us sensitive to the life: with all people without any differences. This new education, would not be a formal teaching, rather be a facilitation process of feeling life with awareness which would connect us with life through music, dance, mind watching, laughing, sports etc. 


\section{References}

David Hume(1739-40), treatise of Human Nature. London

Goffman. E 1963. Stigma: notes on the management of Social . London, Penguin (Google Scholar)

Husserl E (1963), Ideas: A general Introduction to pure phenomenology( translation) Gibson. New York; Collar books

Kant Immanuel(1771) Critique of Pure Reason. London

Levi Strauss Claude 1962. The Savage Mind. University of Chicago Press.

Levi Strauss Claude 1978. Myth and meaning. Routledge And Kegan Paul, London and Henley.

Bibliography:

John D Caputo, 1997. Deconstruction in a nut shell: A conversation with Jacques Derrida. Fordham University

\section{Dr Mohan Singh \\ Asst Prof Department of Sociology Government first grade college for women \\ Krishna Raj Pet (Mysore University) E mail: mohandag2016@gmail.com}

